\section{"Pause-2-Play": a pilot school-based obesity prevention program}

\section{"Pause-2-Play": um programa piloto escolar de prevenção de obesidade}

Gregory Killough 1

Danielle Battram 2

Joanne Kurtz 3

Gillian Mandich 4

Laura Francis 5

Meizi He 6

${ }^{1}$ Carlington Community and Health Services, 900 Merivale Road, Ottawa, ON.

2,3,5 Brescia University College, 1285 Western Road, London, ON.

4 Middlesex-London Health Unit, 50 King Street, London, ON.

${ }^{6}$ University of Texas at San Antonio. One UTSA Circle, San

Antonio, TX USA. 78249. E-mail: meizi.he@utsa.edu

\section{Resumo}

Objetivos: "Pause-2-Play" é um programa de prevenção da obesidade direcionado aos comportamentos sedentários relacionados ao uso de monitores de computador e televisores, visando promover a atividade fisica entre estudantes de escolas de educação básica. $O$ programa trata-se de um currículo de modificação comportamental e um programa extracurricular de promoção de saúde. Este estudo-piloto relata sobre a viabilidade, praticidade e impacto do programa.

Métodos: o programa de doze semanas foi implementado com 32 alunos escolares do quinto e sexto grau. A viabilidade e a praticidade do programa foram avaliadas a partir de uma abordagem qualitativa. Os efeitos da intervenção foram avaliados por meio de comparação de mudanças de IMC pré e pós, composição corporal, escores de capacidade física, tempo passado diante um monitor ou televisor, e variáveis cognitivos relacionados aos comportamentos que envolvem o uso de monitor ou televisor.

Resultados: percebeu-se que "Pause-2-Play" foi um programa útil e lúdico cujos vários beneficios incluiam: o fato das crianças ter experimentado novos alimentos, uma sensação de melhor forma física e uma auto-imagem da forma do corpo mais positiva, e uma conscientização aumentada em relação a estilos de vida saudáveis. A intervenção resultou numa redução estatisticamente significativa na porcentagem de gordura corporal e um aumento no indice de massa livre de gordura em crianças portadoras de sobrepeso; um decréscimo na circunferência da cintura e um aumento no índice de massa livre de gordura foram observados em crianças eutróficas. Além disso, a intervenção levou a uma melhoria nos escores de capacidade física tanto entre as crianças eutróficas como entre as portadoras de sobrepeso.

Conclusões: "Pause-2-Play" mostrou se viável e praticável e mudou a composição corporal e os niveis de capacidade fisica de forma favorável.

Palavras-chave Obesidade, Estudantes,
Comportamento




\section{Introduction}

Childhood obesity is a preventable precursor of adverse health outcomes, including type 2 diabetes, acute coronary episodes, asthma, and a host of psychological disorders. ${ }^{1-3}$ The total direct health care cost of physical inactivity and obesity in Canada in 1999 was calculated at $\$ 2.1$ billion. ${ }^{4}$ It follows that an increase in the prevalence of obesity will result in increased costs to the Canadian health care system. The high prevalence of childhood obesity coupled with the health consequences and heavy economic burden warrant research to create and evaluate interventions aimed at decreasing the prevalence of obesity in Canadian children and young people.

Sedentary behaviour is one of the major factors contributing to childhood obesity. Extensive television (TV) viewing and computer use have been consistently associated with overweight and obesity in North American children.5-10 Reducing children's screen time and increasing physical activity offers a promising opportunity to prevent obesity. Recent trials have shown that restricting TV viewing time is effective in decreasing children's adiposity and Body Mass Index (BMI).11-13 Currently, minimal information pertaining to interventions aimed at reducing screen-related sedentary behaviours is available for Canadian settings. It is imperative that effective obesity intervention strategies targeting sedentary behaviours be developed in a Canadian context.

The objective of this pilot study was to test the feasibility and assess the impact of a school-based obesity prevention program, "Pause-2-Play," that aimed to reduce screen time and increase physical activity levels among Canadian children in grades five and six.

\section{Methods}

This pilot program used a pre-post design and targeted all grade five and six students in a single elementary school in a low-income neighbourhood in London, Ontario, Canada. The study was approved by the Research Ethics Board at the University of Western Ontario.

Informed written parental consent and child assent were obtained from 35 out of 70 students $(50 \%)$. Among these, 32 completed the study ( $82 \%)$. The subjects' baseline characteristics are described in Table 1. Forty-nine percent of the subjects had a BMI above the $85^{\text {th }}$ percentile and were thus considered overweight or obese (Table 1). For family demographic information, data were only available for 19 out of 32 parents who returned a brief demographic questionnaire. Of the responding participants, $79 \%$ of children came from two-parent families; $74 \%$ of parents had at least some college or university education and $63 \%$ were employed full time. Additionally, $40 \%$ of the children were white, while a further $42 \%$ were either Arab or Asian, and $37 \%$ of families had a family income below the poverty line $(\$ 39,000$ a year for a family of four in 2007). ${ }^{14}$

Table 1

Characteristics of study subjects at baseline.

\begin{tabular}{|c|c|c|}
\hline & Mean & SD \\
\hline Child's age (years) & 10.58 & 0.66 \\
\hline BMI $\left(k g / m^{2}\right)$ & 20.73 & 3.95 \\
\hline Waist circumference $(\mathrm{cm})$ & 74.04 & 9.12 \\
\hline Percentage body fat $(\%)$ & 25.15 & 10.2 \\
\hline \multirow[t]{2}{*}{ Fat free mass $(\mathrm{kg})$} & 31.88 & 4.98 \\
\hline & $\mathbf{N}$ & $\%$ \\
\hline \multicolumn{3}{|l|}{ Grade } \\
\hline 5 & 24 & 72.7 \\
\hline 6 & 9 & 27.3 \\
\hline \multicolumn{3}{|l|}{ Gender } \\
\hline Boys & 14 & 42.4 \\
\hline Girls & 19 & 57.6 \\
\hline \multicolumn{3}{|l|}{ Weight Status } \\
\hline BMI $<85^{\text {th }}$ percentile & 20 & 51.3 \\
\hline BMI > 85th percentile & 19 & 48.7 \\
\hline
\end{tabular}

Staff and parents were invited to participate in focus groups upon the completion of the program. Informed written consent was also obtained prior to data collection.

"Pause-2-Play" was a 12 week intervention consisting of a Behavioural Modification Curriculum (BMC) and Health Promoting Afterschool Program (HPAS). The BMC was adapted from an existing effective school program, called "Switch-Play," in Australia.15 This six-lesson curriculum focuses on raising awareness, monitoring sedentary behaviour, and setting goals for a more active lifestyle. This curriculum was implemented by teachers in the classroom. The HPAS program was delivered three times per week throughout the intervention and was free of charge to participants. 
This component was adapted from the MCG FitKid Program in Georgia, USA. 16,17 The HPAS aimed at reducing children's exposure to screens and increasing physical activity opportunities by utilizing school playgrounds and gyms during a twohour block after-school. Each session lasted 120 minutes. The first 40 minutes were used for participants to have a healthy snack and to participate in the academic enrichment activities with assistance from an on-going Homework Club delivered by university student volunteers. Of the 80 minutes available for physical activities, about 25 minutes were devoted to warm-up and skill instruction in a variety of activities. The next 40 minutes involved the types of vigorous aerobic activities appropriate for children this age; the exercise was performed in intermittent bouts of varying intensity. The final 15 minutes involved strength and flexibility exercises. The physical activity component was delivered by trained Pause-2-Play program staff.

The implementation process was monitored by subjects' attendance of the after-school program. The feasibility of the intervention was assessed using qualitative research methods. Two separate focus groups were conducted with parents of participants and participants themselves, respectively. Two indepth interviews were conducted with teachers involved in teaching the curriculum and one with the school principal. To avoid potential bias, two external facilitators were hired to conduct the focus groups and interviews. The focus groups were recorded and all participants were informed of the recording prior to the start of the session. Each focus group lasted approximately one hour, and they were recorded and transcribed verbatim. The staff interviews were audio recorded but not transcribed: notes were taken by the moderator and co-moderator during the interviews.

Outcome measures included Body Mass Index (BMI), waist circumference, body composition, fitness level, screen-viewing/use behaviours, children's enjoyment, attitude and self-efficacy related to screen-viewing/use behaviours. Data were collected by trained program staff at baseline and upon completion of the 12 week program.

Children's weights and heights were measured according to a standardized procedure and BMI $\left(\mathrm{kg} / \mathrm{m}^{2}\right)$ was calculated. Children's waist circumference was measured at the midway point between the iliac crests and the lower ribs, when the subject was standing erect with feet together. Body composition was assessed using bio-electrical impedance analysis (BIA, TANITA Body Composition Analyzer, TBF410 , Japan). Subjects were asked to void before the measurement. Measurements were taken twice and an average of the two values was calculated. Fat-free Mass Index [FFM (kg)/height (m)2] was calculated. 18 A 20-Meter Shuttle Run Test (20-MSR) was used to measure fitness levels utilizing a standard protocol. The same personnel conducted the test to minimize random errors.

Screen-viewing behaviours were measured using the Child Sedentary Behaviour Questionnaire (CSBQ). ${ }^{19}$ Children reported the usual time spent watching TV, using the computer and playing electronic games on weekdays and weekends. Children's enjoyment of and attitude towards screen-viewing behaviours and self-efficacy for spending less time in screen-related activities were measured using a validated instrument by Norman et al. 20 To assess unintended adverse body image-related consequences from the intervention, we adopted a short instrument from the Switch-Play study. 21 The questionnaire was administered in the classroom under the instruction of trained program staff.

A short questionnaire to assess sociodemographics was sent home to be filled out by parents or guardians at the end of the program.

All quantitative data were entered into SPSS Version 16. The BMI percentile and BMI Z-score were calculated using Epi-Info software developed by the Center for Disease Control (CDC). The Generalized Linear Model (GLM) Repeated Measures Model was used to compare pre-post changes in BMI Z-score, percent body fat, and fatfree mass index, adjusted for program attendance rate. Paired t- tests were used to determine pre-post changes in fitness score, screen time, attitude and enjoyment with regard to screen use, self-efficacy in reducing screen time, as well as body image scores.

Qualitative data were analyzed using a combination of the editing and template organizing styles outlined by Miller and Crabtree. 22 Several techniques were used to promote the trustworthiness and credibility of the findings. To ensure credibility, member checking (a process of verifying the findings) was completed at the end of each interview to confirm that the interviewer correctly understood the participant's responses. To ensure confirmability, two researchers performed inductive content analysis independently and simultaneously. They also met to combine and compare their independent analyses. As the analysis proceeded, a coding template evolved that allowed for the expansion of key themes; this was assisted by the computer software package QSR Nvivo (QSR Nvivo 2, released in 2002 by QSR International, Victoria, Australia). A summary of the analysis was prepared and reviewed 
by a third team member who independently read all the transcripts and debriefed the interviewers.

\section{Results}

Eleven children participated in two focus group discussions. "Pause-2-Play" was perceived by participants as a good, fun program that provided them the opportunity to play, do homework, try healthy snacks, meet new friends, and receive mentorship. Children's perceived benefits for participating in "Pause-2-Play" included, but were not limited to, trying new snacks, feeling fitter, feeling better about one's own body image, becoming more aware of a healthy-lifestyle, improving skills, developing an aptitude for certain sports, and providing a way to receive homework help. Participants enjoyed "Pause-2-Play" and felt sad when "Pause-2-Play" ended, but also provided feedback for further improvement of the program. Suggestions included more fun and more variety in homework, a greater variety of physical activities, going outside whenever weather allowed, and being more sensitive to food restrictions when offering healthy snacks (Table 2).

Thirteen parents participated in the focus group discussions. All parent focus group participants perceived "Pause-2-Play" as a good program that integrated three key components of their children's well-being: healthy eating, homework assistance, and active living. They saw the need for such a program, especially during winter and inclement weather, when parents were not at home and children had no place to go after school. Parents also perceived the program as an excellent social opportunity for children to develop much needed interpersonal skills.

Parents perceived many benefits of their children being in the program. They remarked that "Pause-2Play" not only increased physical activity levels and

Table 2

Children's perceptions of "Pause-2-Play".

\section{Overall impression}

"I think it's a very, very fun program for us."

"I want to do it next year in Grade 6. I want you guys to come back again."

\section{Perceived benefits}

Healthy snack:

"Good because usually they are healthy snacks and they were always healthy. The thing that I liked about the snacks some of them I never ever tried and I always liked and I got to try new dips."

"Sometimes when I try the food and I liked it, I asked my parents to buy it at the grocery store and we'd eat it." Homework:

"I am going to miss the homework and the games too because when you get to go home, you have no homework then you can go outside and play. And if you come to this club, you can finish your homework."

Increased awareness of healthy lifestyle:

"I learned that there's way more other things to do than just watch TV so I actually watch less TV now."

"I notice usually when I come home and I feel like an after school snack, I'll get like a bowl of chips or something but usually I've been grabbing like celery and carrots and not even knowing. Just like I've just started in the habit after this, ever since we started this."

\section{Suggestions for program improvement}

Healthy snack:

"So to be sensitive to, for example, if you have Muslim people that don't eat, sometimes Jewish people don't eat pork and that kind of thing, be sensitive to that."

Homework:

"I think they should have more activities that are more fun, not like more boring ones. So I'm interested in doing the math sheets but try to make it a little more fun."

Physical activity:

"the most important advice I think is to give more variety because kids are going to get bored of the same thing over and over. They want to do something new each time."

"I enjoyed the dancing and the stretches, but they should be shorter. And when we play the games, I think we should have a little bit more variety." 
decreased screen time, but it also increased awareness regarding a healthy lifestyle, increased confidence, heightened self-esteem, positively changed eating behaviours, improved academic performance, helped children establish healthy routines (eating healthy snacks, doing homework and actively playing), brought about favourable changes in body shape, and reduced body weight. Furthermore, parents noticed that children in the "Pause-2-Play" program became role models for their younger siblings in terms of healthy eating and physical activity, as well as positively influencing healthier choices made by the entire family. Parents also identified a few challenges such as the lack of a school bus program after the HPAS. They suggested that the program be extended beyond 12-weeks and that the program should also be offered to other school-aged children.

It appears that some parents were not aware of the 6-lesson "Pause-2-Play" BMC delivered by classroom teachers and were not fully engaged in helping their children reduce screen time at home (Table 3).

The school principal and teachers remarked that "Pause-2-Play" was a needed program that uses after-school time to help students develop academically and physically. School staff members were very supportive of the program and would like to see "Pause-2-Play" expanded to more schools. Staff believed that the curriculum itself was welldesigned, adequately described in the training manual, and aligned well with the objectives of the Ontario curriculum that they already teach.

Teachers identified two significant areas for

Table 3

Parents' perspectives on "Pause-2-Play".

Overall impression

"But it's kind of like a discipline. This discipline, as we said, physical fitness, study, and healthy snacks - it's a good combination. That made the quality of the program and this is good quality."

"I think just making good choices about getting your homework done and making the choice to be physically active instead of just sitting around watching TV or something. You can never have too much of that. That's a good message to get across to them."

"My child, she likes it. She's happy. She is happy doing activities at the school, she likes it. When I pick her up ten or five minutes early, she doesn't want to come with me."

"[My child] is not a really, really athletic kid, so it gave her an opportunity to try out lots of things."

Perceived benefits to the child

"I like the physical fitness part of it. She [my child] got out and was doing stuff she wouldn't really do on a regular basis, running around, like that."

"You know, but [my child] does eat healthier now. She is a big junk food junky, and for me to get her to eat those rice cakes, and I bought them for her lunch now and she likes them and I'm like wow. And she is definitely eating better now. And I think because she did see the weight loss."

"[My child's] confidence level, that's what I've noticed, and I think yes it is the program. I think it's this group itself and interacting with different kids, not just the ones she plays with in school that I think has made the big difference." "[My child] thoroughly enjoyed the program and I've even seen improvement in her marks, so I am really pleased."

\section{Perceived benefits to the family}

"I found that it really supported the family. It wasn't just that one child benefited from it. It was about it having a trickle-down effect on the whole family."

\section{Suggestions for program improvement}

"I think that if you are going to run a homework component it would be helpful to liaise with the teacher and say let's red flag a couple of kids that might need extra, not extra but know a little bit more about how specifically to interact with them."

"Well, it wasn't really convenient because I'm home from work at 5 or 5:15 and there's flute lesson at 6:30 or choir practice at 6 so it's a bit of a rush but we have an older son who helps out too so we made it work, and happy to do so. We'd do it again."

"I think we need more time to change the whole family. Three months is not enough."

"if you could run it all school year, that would be great. I know she would come, for the whole school year, she would come." 
improvement in implementing the program at an elementary school. It was suggested that there needed to be more clear communication between program staff and school staff to increase the efficiency with which the BMC could be incorporated. The second concern was that teaching the BMC was difficult given their already busy schedules. It was suggested that the responsibility for teaching the six lesson BMC could be undertaken by "Pause-2-Play" staff during the homework club (Table 4).

The pre-post intervention changes in BMI, waist circumference and body composition are presented in Table 5. For overweight and obese subjects, the intervention resulted in a reduction in percent body fat $(2.9 \%, p<0.05)$ and an increase in fat-free mass index $\left(0.8 \mathrm{~kg} / \mathrm{m}^{2}, p<0.05\right)$; however, there was no statistically significant decline in BMI Z-scores. For normal weight subjects, the intervention resulted in $1.7 \mathrm{~cm}$ decrease in waist circumference $(p<0.05)$. The intervention improved fitness scores by 2 laps $(p<0.05)$, but decreased self-efficacy scores by 1.8 units $(p<0.05)$ (Table 6).

Table 4

School principal and teacher's perceptions on "Pause-2-Play".

\section{A needed program}

"The students I have spoken with all agreed that the extra time spent having someone explain a math or language concept made all the difference."

"Students who normally do not get their work done got their work done."

"Students had an opportunity to try a variety of different physical activities, especially ones that they have never tried before."

\section{A successful program with numerous benefits}

"The program promotes and reinforces healthy lifestyle choices regarding food and exercise."

"The after school program has delivered very concrete evidence of success, such as, for example, greater stamina and even weight loss among our students in particular."

"Ultimately, the value of any project is what remains when it is over. Everyone here at our school has seen the difference. Our kids are more engaged, energetic and confident in their studies."

\section{Concerns and suggestions}

"Teachers already have a lot of responsibility. The in-class part of Pause-2-Play adds to their workload. It would help to look into having these lessons included in the after-school program."

"The teachers have to help with disciplining the students. The Pause-2-Play staff did as much as they could and did a good job. In the future, make sure that the program staff understand the discipline system and documentation used at the school. This consistency will help a lot with behaviour problems."

"There needs to be clear communication between teachers and the Pause-2-Play staff. The expectations of the teachers need to be clear, and these discussions should happen well in advance of the program starting so that it can be incorporated into the teacher's lesson planning. Ideally, you would talk to them before the school year starts."

Table 5

Pre- and post-intervention changes in anthropometrics and body composition by weight status*.

\begin{tabular}{|c|c|c|c|c|c|c|}
\hline \multirow[t]{2}{*}{ Outcome measures } & \multicolumn{3}{|c|}{$B M I<85^{\text {th }} \quad(n=17)$} & \multicolumn{3}{|c|}{$B M I \geq 85^{\text {th }} \quad(n=15)$} \\
\hline & Baseline & Endpoint & $p$ & Baseline & Endpoint & $p$ \\
\hline BMI Z-score & $0.14 \pm 0.19$ & $0.12 \pm 0.22$ & 0.74 & $1.61 \pm 0.09$ & $1.57 \pm 0.09$ & 0.130 \\
\hline Waist circumference $(\mathrm{cm})$ & $67.5 \pm 1.32$ & $65.8 \pm 1.12$ & 0.031 & $81.16 \pm 1.67$ & $80.97 \pm 1.90$ & 0.810 \\
\hline Percent body fat (\%) & $19.3 \pm 1.44$ & $18.8 \pm 1.56$ & 0.42 & $32.7 \pm 2.22$ & $29.8 \pm 1.62$ & 0.022 \\
\hline Fat-free Mass Index $\left(\mathrm{Kg} / \mathrm{m}^{2}\right)$ & $14.40 \pm 0.25$ & $14.63 \pm 0.29$ & 0.053 & $15.68 \pm 0.30$ & $16.44 \pm 0.31$ & 0.048 \\
\hline
\end{tabular}

* Values have been adjusted for attendance of the "Pause-2-Play" after-school program; BMI= Body Mass Index. 
Pre- and post-intervention changes in fitness level, screen-viewing behaviours and cognitive measures.

\begin{tabular}{|c|c|c|c|c|c|}
\hline \multirow[t]{2}{*}{ Outcome measures } & \multirow[t]{2}{*}{$\mathbf{N}$} & \multicolumn{2}{|c|}{ Mean } & \multirow{2}{*}{$\begin{array}{l}\text { Mean difference } \\
\pm \text { s.e. }\end{array}$} & \multirow[t]{2}{*}{$p$} \\
\hline & & Baseline & Endpoint & & \\
\hline Fitness Score (\# of Laps) & 31 & 17.0 & 19.0 & $-2.00 \pm 0.72$ & 0.009 \\
\hline \multicolumn{6}{|l|}{ Screen time (hours) } \\
\hline weekday (Monday - Friday) & 31 & 13.3 & 10.9 & $2.48 \pm 1.41$ & 0.088 \\
\hline weekend (Saturday - Sunday) & 30 & 5.53 & 6.1 & $-0.59 \pm 1.19$ & 0.630 \\
\hline \multicolumn{6}{|l|}{$\begin{array}{l}\text { Screen viewing attitude score } \\
\text { (positive } \rightarrow \text { negative) }\end{array}$} \\
\hline (Cronbach's Alpha $=0.84$ ) & 21 & 31.8 & 31.1 & $0.62 \pm 1.24$ & 0.620 \\
\hline \multicolumn{6}{|l|}{$\begin{array}{l}\text { Screen viewing enjoyment } \\
\text { score (high } \rightarrow \text { low) }\end{array}$} \\
\hline (Cronbach's Alpha $=0.71)$ & 29 & 18.1 & 17.1 & $1.01 \pm 0.94$ & 0.290 \\
\hline \multicolumn{6}{|l|}{$\begin{array}{l}\text { Self-efficacy score in reducing } \\
\text { screen time (high } \rightarrow \text { low) }\end{array}$} \\
\hline (Cronbach's Alpha $=0.85$ ) & 31 & 17.9 & 19.7 & $-1.74 \pm 0.69$ & 0.017 \\
\hline \multirow{2}{*}{\multicolumn{6}{|c|}{$\begin{array}{l}\text { Body image score } \\
\text { (negative } \rightarrow \text { positive) }\end{array}$}} \\
\hline & & & & & \\
\hline (Cronbach's Alpha $=0.80$ ) & 32 & 6.8 & 6.2 & $0.56 \pm 0.41$ & 0.184 \\
\hline
\end{tabular}

\section{Discussion}

The objective of this pilot study was to test the feasibility and effectiveness of a school-based intervention incorporating a BMC and an after-school program aimed at reducing screen-related behaviours among elementary school children. The results indicated that the program was feasible and well received by children, parents, and school staff. The program has favourably changed children's fitness levels and body composition. The limitations and challenges that arose during the course of this pilot project provide valuable insights for future program modification and implementation.

School administration and teachers were key to ensuring the successful implementation of "Pause-2Play". In the current study, school staff were accommodating during both data collection phases and intervention implementation. Teachers' liaising with "Pause-2-Play" staff ensured that participants received the optimal benefits of the homework club. Teachers took on the responsibility for providing the in-class curriculum to students. The "Pause-2-Play" curriculum is aligned with the objectives of the Ontario curriculum, and thus it appeared to be practical to incorporate the six lessons; however, the inclass curriculum was not incorporated equally across all classes nor fully delivered as planned. This inconsistent implementation might have limited the impact of the program on children's enjoyment of and attitude towards screen-viewing behaviours, or their actual screen behaviours. We recommend that future "Pause-2-Play" implementation could adopt one of these two strategies: if teachers are to teach the curriculum, "Pause-2-Play" staff must ensure that the commitment required is discussed in advance, ensuring that teachers have sufficient time to incorporate the "Pause-2-Play" curriculum into their lesson plans. It is also vital that all teachers allocate a similar amount of time and energy to the curriculum. The second potential strategy is to remove the burden from the teachers and allocate program staff to deliver the curriculum one day per week for the first six weeks of the after-school program.

Successful implementation of "Pause-2-Play" also hinged upon participants' engagement and enjoyment of the program. Student participants in the current study perceived "Pause-2-Play" to be an enjoyable, fun program. Parents echoed this sentiment, suggesting that their children enjoyed attending the program. Recruiting and retaining participants is a critical issue so far as feasibility is concerned: if participants do not enjoy the program, 
they may withdraw. It was evident that "Pause-2Play" was well received by both children and their parents because of the relatively high retention rate - which was $82 \%$. Children's suggestions, such as having more fun and more variety in the homework club, a greater variety of physical activities, going outside when weather permitted, and being more sensitive to food restrictions when offering healthy snacks, should be incorporated into future "Pause-2Play" implementation.

It is encouraging that this 12 -week intervention has achieved improvements in body composition and fitness levels comparable to studies of notably longer duration. The MCG FitKid Program decreased body fat percentage measures by less than one percent in each of the first two years of the program. 16 The improvement in fitness is important for both normal weight and overweight children, given that three out of five Canadian youth are not active enough to achieve health benefits and $26 \%$ are overweight or obese. 23 The "Pause-2-Play" intervention provided an environmental opportunity that encouraged moderate-to-vigorous physical activity, which is necessary for improved health. Such opportunities are extremely important for children from low SES families, as they are at a great risk of being overweight or obese 24 and their parents are less able to afford sports or recreational programs.

It is unclear why children's self-efficacy with regard to spending less time on screen-related activities decreased at the end of the intervention. In the Switch-Play study, children in the behavioural modification intervention reported spending more time on screen-related activities than those in the control group. Salmon et al. 21 speculated that the intervention may have increased children's awareness of and engagement with the targeted behaviour, which was an undesirable outcome. They also suspected that it may be due to the 'response shift bias'.21,25 Response shift bias refers to a phenomenon of learning effects, in which participants may know little about a behaviour before the intervention and learn about it as a result of the intervention. A baseline measure may thus be subject to substantial error and a favourable shift in the accuracy of reporting may occur at the end of the intervention. 21,25 The decline in self-efficacy in the current study may be a result of an undesired outcome or "response shift bias". Nonetheless, further attention and investigation are required to avoid potential undesired outcomes when implementing behavioural modification curricula targeting screen-related sedentary behaviours.

There were a number of limitations to this pilot study. For instance, a one-sample pre-post design was used in evaluating the impacts of the program. Although such a design is considered suitable for a pilot study, it may have compromised internal validity. The sample size was relatively small which may decrease statistical power in evaluating program impacts. Future large-scale implementation and evaluation of "Pause-2-Play" should use a randomized controlled trial design with sufficient sample size.

"Pause-2-Play" was well received by children, parents, and school staff. The program was feasible, practical, and favourably changed body composition and fitness levels. After-school obesity prevention programs for children represent one potentially viable solution in the battle against childhood obesity in Canada.

\section{Acknowledgements}

The authors are grateful to Dr. Jo Salmon, lead investigator of the Switch-Play Study, Australia, and Dr. Zenong Yin, lead investigator of the MCG FitKid study, USA, for providing support and for sharing their experience and intervention resources. The authors are grateful to Ms. Charlene Beynon, Director of the Public Health Research Education and Development Program, Middlesex-London Health Unit, Ms. Donnafaye Milton, Brescia Outreach Coordinator, Mr. Dan Lavery, Principal of the participating school, and Brescia University College student volunteers for their support and involvement throughout the project. Special thanks are also extended to school staff as well as the student participants and their parents for making this project possible.

\section{References}

1. Alter D, Eny K. The relationship between the supply of fast-food chains and cardiovascular outcomes. Can J Public Health. 2005; 96: 173-7.

2. Janssen I, Katzmarzyk P, Boyce W, King M, Pickett W. Overweight and obesity in Canadian adolescents and their associations with dietary habits and physical activity patterns. J Adolesc Health. 2004; 35: 367.
3. Reilly J. Descriptive epidemiology and health consequences of childhood obesity. Best Pract Res Clin Endocrinol Metab. 2005; 19: 507-26.

4. Katzmarzyk PT, Janssen I. The economic costs associated with physical inactivity and obesity in Canada: an update. Can J Appl Physiol. 2004; 29: 90-115. 
5. Hanley AJ, Harris SB, Gittelsohn J, Wolever TM, Saksvig B, Zinman B. Overweight among children and adolescents in a Native Canadian community: prevalence and associated factors. Am J Clin Nutr. 2000; 71: 693-700.

6. Robinson TN. Television viewing and childhood obesity. Pediatr Clin North Am. 2001; 48: 1017-25.

7. Hernandez B, Gortmaker SL, Colditz GA, Peterson KE, Laird NM, Parra-Cabrera S. Association of obesity with physical activity, television programs and other forms of video viewing among children in Mexico city. Int J Obes Relat Metab Disord. 1999; 23: 845-54.

8. Dennison BA, Erb TA, Jenkins PL. Television viewing and television in bedroom associated with overweight risk among low-income preschool children. Pediatrics. 2002; 109: 1028-35.

9. Lowry R, Wechsler H, Galuska DA, Fulton JE, Kann L. Television viewing and its associations with overweight, sedentary lifestyle, and insufficient consumption of fruits and vegetables among US high school students: differences by race, ethnicity, and gender. J Sch Health. 2002; 72: 41321.

10. Eisenmann JC, Heelan KA, Welk GJ. Assessing body composition among 3- to 8-year-old children: anthropometry, BIA, and DXA. Obes Res. 2004; 12: 1633-40.

11. Faith MS, Berman N, Heo M, Pietrobelli A, Gallagher D, Epstein LH, Eiden MT, Allison DB. Effects of contingent television on physical activity and television viewing in obese children. Pediatrics. 2001; 107: 1043-8

12. Robinson TN. Reducing children's television viewing to prevent obesity: a randomized controlled trial. JAMA. 1999; 282: 1561-7.

13. Epstein LH, Paluch RA, Gordy CC, Dorn J. Decreasing sedentary behaviors in treating pediatric obesity. Arch Pediatr Adolesc Med. 2000; 154: 220-6.

14. Statistics Canada. Income, pensions, spending and wealth. [on line] 2008. http://www.statcan.gc.ca/subjectsujet $/$ themetheme.action?pid $=3868$ \&lang $=$ eng $\&$ more $=0$ [2009 Aug 22]

15. Dietz WH. The obesity epidemic in young children. Reduce television viewing and promote playing. BMJ. 2001; 322 313-4.
16. Gutin B, Yin Z, Johnson M, Barbeau P. Preliminary findings of the effect of a 3-year after-school physical activity intervention on fitness and body fat: the Medical College of Georgia Fitkid Project. Int J Pediatr Obes. 2008; 3 (Suppl 1): 3-9.

17. Yin Z, Hanes JJr., Moore JB, Humbles P, Barbeau P, Gutin B. An after-school physical activity program for obesity prevention in children: the Medical College of Georgia FitKid Project. Eval Health Prof. 2005; 28: 67-89.

18. VanItallie TB, Yang MU, Heymsfield SB, Funk RC, Boileau RA. Height-normalized indices of the body's fatfree mass and fat mass: potentially useful indicators of nutritional status. Am J Clin Nutr. 1990; 52: 953-9.

19. He M, Ng V, Malik A. Reliability and validity of the Child Sedentary Activity Questionnaire (CSAQ). Ontario Public Health Association. Public Health: The Best Health Investment. Proceedings of OPHA 55th Annual Conference; 2004 Nov 22; Toronto, ON.

20. Norman GJ, Schmid BA, Sallis JF, Calfas KJ, Patrick K Psychosocial and environmental correlates of adolescent sedentary behaviors. Pediatrics. 2005; 116: 908-16.

21. Salmon J, Ball K, Hume C, Booth M, Crawford D Outcomes of a group-randomized trial to prevent excess weight gain, reduce screen behaviours and promote physical activity in 10-year-old children: switch-play. Int J Obes (Lond). 2008; 32: 601-12.

22. Miller WL, Crabtree BF. Clinical research: a multimethod typology and qualitative roadmap. In: Crabtree BF, Miller WL, eds. Doing qualitative research. Sage, CA, Thousand Oaks; 1999. p 3-30.

23. Bryan S, Walsh P. Physical activity and obesity in Canadian women. BMC Womens Health. 2004; 4 (Suppl 1): S6.

24. Moffat T, Galloway T, Latham J. Stature and adiposity among children in contrasting neighborhoods in the city of Hamilton, Ontario, Canada. Am J Hum Biol. 2005; 17: 35567

25. Baranowski T, Klesges LM, Cullen KW, Himes JH. Measurement of outcomes, mediators, and moderators in behavioral obesity prevention research. Prev Med. 2004; 38: $1-13$.

Recebido em 19 de julho 2010

Aprovado em 12 de agosto de 2010 